\title{
PELATIHAN PEMBUATAN LEMBAR KERJA PESERTA DIDIK BERBASIS KEARIFAN LOKAL SURAKARTA DI KECAMATAN BANJARSARI
}

\author{
Ema Butsi Prihastari ${ }^{1}$, Ratna Widyaningrum ${ }^{2}$ \\ FKIP, Universitas Slamet Riyadi
}

Email: butsinegara@gmail.com ${ }^{1}$, ratnawidya33@gmail.com²

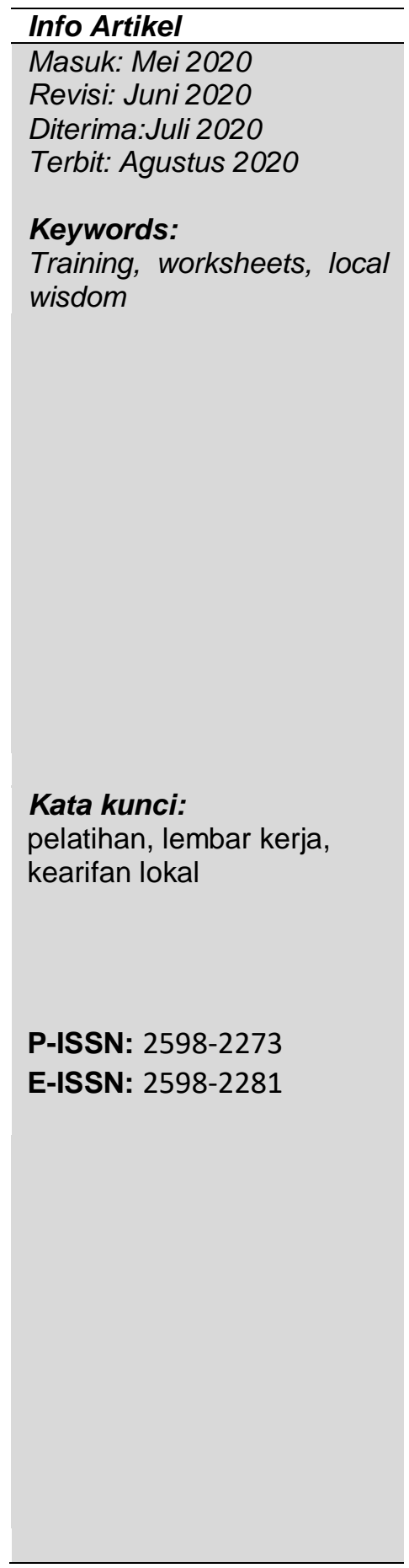

\begin{abstract}
The challenge in presenting meaningful learning that teaches concepts in a guided way and can evaluate the ability of students directly as well as the diversity of local wisdom of Surakarta which still has not been integrated with learning materials, especially in elementary school is a reason to hold this devotion. The objectives achieved from this devotion program of training in the creation of learners based on local wisdom worksheet in Banjarsari District can add insight and help elementary school teachers in Banjarsari district in order to contract students ' knowledge and reduce the teacher centered paradigm through the integration of local wisdom of Surakarta which is associated with teaching materials. The method of implementation is conducted through participatory approach: a) participative, b) awareness, c) learning (theory and practice), and $D$ ) reflective. Meanwhile, the mechanism of implementation of devotion includes: a) preparation and $B$ ) Implementation of training include material presentation, assignment making LKPD, activity evaluation, reflection and closure of activities. Based on the results of evaluation and reflection, there were significant changes and improvements in integrating local wisdom in the form of worksheets to improve student learning outcomes.
\end{abstract}
Abstrak
Tantangan dalam menyajikan pembelajaran bermakna yang mengajarkan konsep secara terbimbing dan dapat mengevaluasi kemampuan peserta didik secara langsung serta beraneka ragamnya kearifan lokal Surakarta yang masih belum terintegrasi dengan materi pembelajaran khususnya di Sekolah Dasar menjadi alasan untuk mengadakan pengabdian ini. Tujuan yang dicapai dari program pengabdian ini pelatihan pembuatan Lembar Kerja Peserta Didik Berbasis Kearifan Lokal yang dilaksanakan di kecamatan Banjarsari dapat menambah wawasan dan membantu para guru Sekolah Dasar di kecamatan Banjarsari dalam mengkontruk pengetahuan peserta didik dan mengurangi paradigma teacher centered melalui integrasi kearifan lokal Surakarta yang dikaitkan dengan materi ajar. Metode pelaksanaan yang dilakukan melalui metode pendekatan: a) partisipatif, b) penyadaran, c) pembelajaran (teori dan praktek), dan d) reflektif. Sedangkan, mekanisme pelaksanaan pengabdian meliputi: a) persiapan dan b) pelaksanaan pelatihan meliputi penyajian materi, penugasan membuat LKPD, evaluasi kegiatan, refleksi serta penutupan kegiatan. Berdasarkan hasil evaluasi dan refleksi didapatkan perubahan yang signifikan dan peningkatan dalam mengintegrasikan kearifan lokal yang berbentuk lembar kerja guna meningkatkan hasil belajar peserta didik. 


\section{PENDAHULUAN}

Pengembangan kurikulum 2013 didasarkan pada salah satunya hasil TIMSS, dimana hanya $5 \%$ peserta didik Indonesia yang dapat mengerjakan soal kategori tinggi dan hasil PISA yang menunjukkan Indonesia ada di peringkat 64 dari 65 negara. Diharapkan dengan adanya pengembangan kurikulum dapat meningkatkan hasil belajar peserta didik. Hasil belajar yang diharapkan tidak hanya berorientasi pada kognitif saja. Hal tersebut sesuai dengan tujuan pendidikan yang tercantum dalam UU No. 20 tahun 2003 pasal 3 tentang Sistem Pendidikan Nasional bahwa setiap lembaga pendidikan hendaknya lebih berfokus pada pengembangan potensi peserta didik yang berorientasi pada afektif (sikap dan tingkah laku).

Untuk menumbuhkan potensi peserta didik dan mencapai tujuan pendidikan nasional diperlukan pembelajaran yang baik melalui komunikasi yang baik antara pendidik dan peserta didik. Salah satunya melalui pembelajaran yang dikemas dan dirancang untuk menarik minat belajar mereka. Diantaranya melalui pendidikan yang berbasis kearifan lokal yang tentunya menjadi bagian yang tidak terpisahkan dari kita sebagai bangsa yang memegang teguh arti "Bhineka Tunggal Ika". Hal tersebut diwujudkan melalui pendidikan yang mengkaitkan konsep materi dengan kehidupan sehari-hari.

Pendidikan merupakan sarana untuk mengembangkan kualitas sumber daya manusia yang memiliki pemikiran kritis, logis, kreatif, komunikasi, kolaborasi, dan berkarakter. Namun, di lapangan peserta didik tidak diarahkan pada kemampuan memahami materi yang dikaitkan dengan kehidupan sehari-hari. Sehingga diperlukan guru yang kreatif dan inovatif untuk membantu peserta didik memahami materi pelajaran. Penerapan kurikulum juga harus didukung dengan berbagai perangkat pembelajaran yang mengajak siswa aktif salah satunya melalui Lembar Kerja Peserta Didik (LKPD).

LKPD dapat membantu peserta didik untuk lebih aktif mengkonstruk pengetahuannya. Menurut Prastowo (2014), LKPD merupakan bahan ajar yang dapat mengurangi paradigma teacher centered menjadi student centered. Dikarenakan posisi guru hanya sebagai fasilitator (Andi Prastowo, 2014). Pembelajaran menjadi bermakna jika apa yang peserta didik dengar dan lihat merupakan hasil temuan mereka sendiri yang dihubungakan dengan kehidupan sehari-hari (Toman, dkk, 2013). Jadi, peserta didik mengalami langsung apa yang dipelajarinya dan konsep akan tertanam dalam ingatan mereka dengan baik.

Berdasarkan hasil wawancara dengan guru-guru di SD N Prawit 1 No.69 Surakarta, bahwa sekolah sudah menerapkan kurikulum 2013 dan sudah mendapatkan pelatihan dari tim Pengabdian tentang analisis kurikulum serta pembuatan bahan ajar berbasis kearifan lokal Surakarta. Bagi mereka hal tersebut sangat bermanfaat, berdasarkan hal tersebut tim pelaksana ingin memberikan pelatihan lanjutan tentang pembuatan LKPD dengan alasan guru merasa kesulitan untuk memahamkan materi kepada peserta didik dari apa yang sudah guru ajarkan pada hari itu juga. Sedangkan guru dikejar deadline tugas administrasi sekolah. 
Kemudian, Peserta didik merasa cepat jenuh jika diminta untuk mengerjakan soal setiap hari dari buku sekolah bahkan terkadang mereka merasa kesulitan untuk memahami makna dari materi yang dibaca karena bahasa dan budaya yang berbeda. Melalui LKPD diharapkan guru dapat mengajarkan konsep secara terbimbing dan mengevaluasi kemampuan peserta didik secara langsung.

Target yang ingin dicapai melalui kegiatan pengabdian kepada masyarakat, sebagai berikut:

1. Guru dapat menerapkan analisis kurikulum berbasis kearifan lokal yang sudah pernah disosialisasikan

2. Guru dapat membuat LKPD berbasis kearifan lokal yang dapat mencapai tujuan instruksional pembelajaran

3. Guru dapat mengimplementasikan hasil pelatihannya di kelas masing-masing.

\section{METODE PELAKSANAAN}

Metode yang diterapkan dalam kegiatan ini adalah ceramah dan pemberian tugas. Dalam pelatihan pembuatan Lembar Kerja Peserta Didik berbasis Keearifan Lokal Surakarta akan diberikan beberapa kegiatan yang meliputi penyajian materi, tanya jawab interaktif terkait materi dan permasalahan guru di kelasnya, dan demonstrasi dari LKPD berbasis kearifan lokal yang dibuat dalam kelompok kerja masing-masing.

Pelaksanaan program ini dilakukan dengan metode pendekatan: a) partisipatif, b) penyadaran, c) pembelajaran (teori dan praktek), dan d) pendampingan dengan uraian sebagai berikut:

\section{a. Pendekatan partisipatif}

Dilakukan koordinasi dengan melibatkan tim pelaksana (dosen dan mahasiswa) dengan mitra (SD N Prawit 1 No. 69 Surakarta) untuk menemukan solusi bagi pihakpihak yang dilibatkan

b. Pendekatan penyadaran

Dilakukan pada guru di SD N 1 Prawit No. 69 Surakarta akan pentingnya LKPD dalam mengembangkan dan menerapkan kurikulum 2013 yang dapat membantu guru dan siswa dalam mencapai tujuan instruksional.

c. Pendekatan teori dan praktek

Dilakukan pemberian materi dengan tatap muka dan diberikan penugasan praktek secara berkelompok untuk membuat LKPD berbasis kearifan lokal Surakarta 


\section{d. Pendekatan reflektif}

Dilakukan dengan evaluasi kegiatan selanjutnya melalui refleksi dan keberlajutan dalam bentuk pendampingan dan monitoring guna menjaga kualitas hasil pelatihan dan meningkatkan kemitraan.

Adapun langkah yang akan ditempuh dalam kegiatan ini mencakup beberapa tahap sebagai berikut :

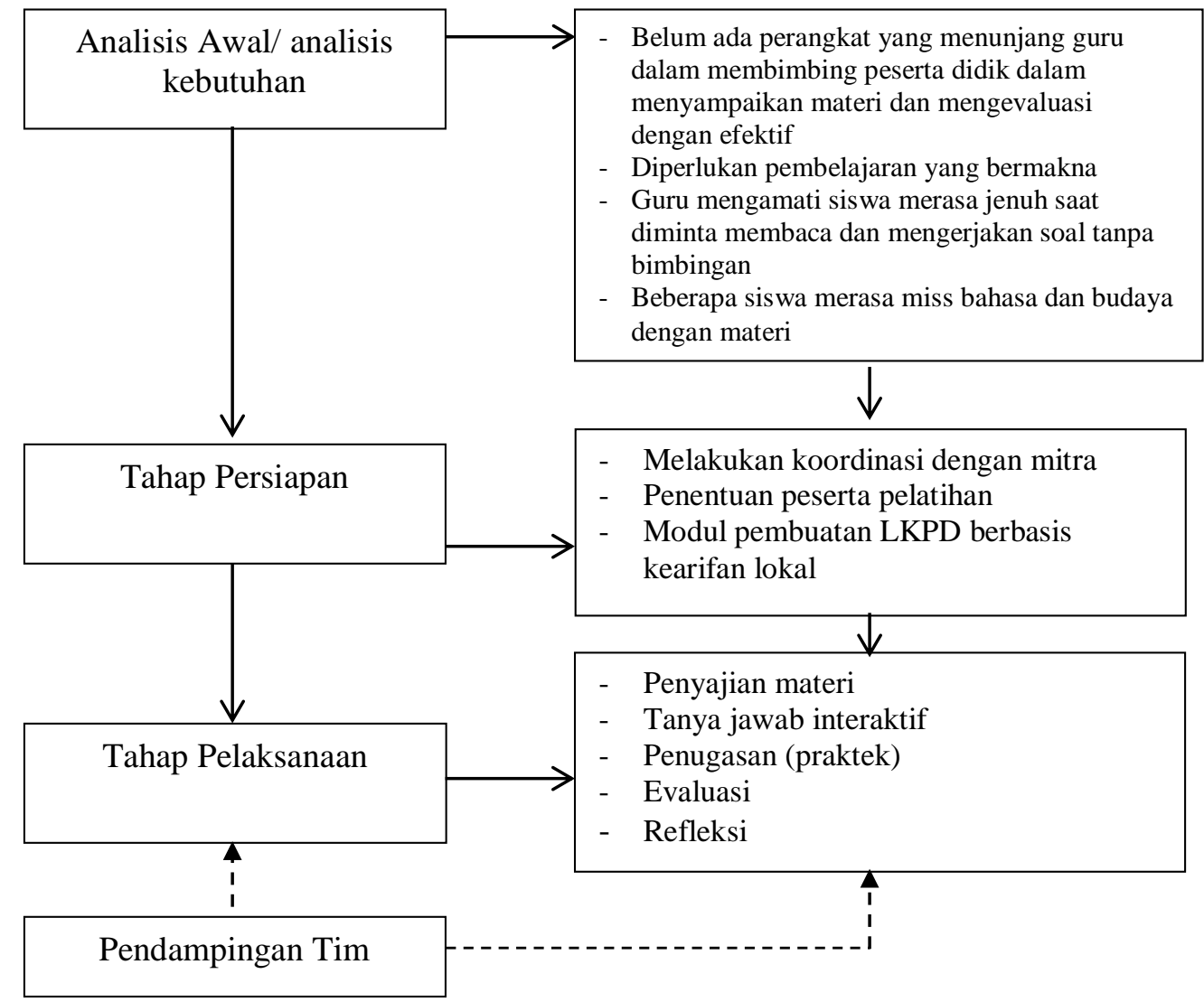

Gambar 1. Skema Pelaksanaan Kegiatan Pengabdian

Dari gambar 1. Dapat dijelaskan mekanisme pelaksanaan kegiatan yang terdiri dari persiapan, pelaksanaan (tindakan), observasi, dan evaluasi dan refleksi, sebagai berikut:

\section{a. Persiapan}

Tahap awal yang dilakukan adalah a) melakukan koordinasi dengan LPPM UNISRI dan SD N Prawit 1 No.69 Surakarta dan merencanakan pelaksanaan operasional, b) penentuan dan rekruitmen peserta pelatihan, c) pembuatan instrumen pelatihan, dan d) persiapan konsumsi, publikasi, sertadokumentasi. 


\section{b. Pelaksanaan Pelatihan}

Pada pelaksanaan kegiatan pembuatan LKPD berbasis kearifan lokal ini terdiri dari empat tahapan, yaitu:

\section{a. Penyajian Materi}

Materi yang disajikan terkait pembuatan LKPD berbasis kearifan lokal dengan pengetahuan dan beberapa materi ajar di Sekolah Dasar yang dipersiapkan guru. Penyajian ini diploting dalam 2 kali tatap muka. Sebelum dilakukan pelatihan diberikan soal pre test tentang evaluasi

b. Tanya jawab interaktif

Tanya jawab dilakukan untuk mengetahui sejauhmana materi yang disampaikan dipahami oleh peserta pelatihan.

\section{c. Penugasan Praktik}

Pada akhir materi peserta membuat 3 (tiga) kelompok kemudian masing-masing kelompok diberikan undian untuk membuat LKPD sesuai dengan undian yang diambil. Setiap kelompok diminta untuk mempresentasikan hasil LKPD yang dibuat dan hasil dari implementasi di kelas masing-masing setelah pelatihan. Tim pengabdian mendampingi, memandu, dan mengarahkan serta memberikan solusi apabila timbul permasalahan selama penugasan praktik.

\section{d. Evaluasi Kegiatan}

Evaluasi kegiatan dilakukan dengan beberapa cara. Evaluasi hasil dilihat dari hasil tugas praktik kelompok. Peserta menampilkan hasil diskusi dan dievaluasi bersama-sama. Dilanjutkan dengan mengerjakan soal post test untuk mengukur keberhasilan pelatihan yang sudah dilaksanakan.

\section{e. Refleksi dan Penutupan Kegiatan}

Di akhir kegiatan peserta dan tim pengabdian melakukan refleksi hasil pelatihan dan para peserta (sekolah mitra) juga memberikan evaluasi akan pelatihan ini dan keberlanjutan program. Setelah semua kegiatan yang direncanakan terlaksana, kemudian ditutup dan pemberian pesan.

Analisis data yang digunakan adalah deskriptif untuk mendeskripsikan data dan temuan dalam bentuk grafik, tabel, dan angka. 


\section{PEMBAHASAN}

Pelaksanaan kegiatan pengabdian kepada masyarakat diisi dengan pemberian materi pembuatan Lembar Kerja Peserta Didik berbasis kearifan lokal yang merupakan hasil pengembangan penelitian dan tindak lanjut sosialisasi integrasi kurikulum 2013 dengan budaya lokal di tahun 2018.

Proses menuju pelatihan di awali dengan ditemukannya permasalahan pembelajaran dalam mengkontruksi materi pada peserta didik hingga harapan tercapainya ketuntasan belajar sesuai indikator terwujud.

Instrumen materi yang dijadikan bahan pelatihan sebelumnya sudah dikembangkan melalui penelitian yang dilakukan di tingkat pendidikan dasar, yaitu Lembar Kerja Peserta Didik yang sudah dikaitkan dengan beberapa mata pelajaran dengan budaya lokal dalam tema.

Menurut Andi Prastowo (2011:204) LKPD merupakan bahan ajar cetak yang berupa lembaran kertas yang berisi materi, ringkasan, dan petunjuk pelaksanaan tugas yang harus dikerjakan peserta didik dengan mengacu pada Kompetensi Dasar yang akan dicapai. LKPD yang disusun dibuat praktis, menarik, dan menciptakan suasana belajar aktif peserta didik. Hal ini tentu akan sangat membantu daam keberhasilan belajar peserta didik seperti pendapat Arliyah dan Ismono (2015:509) bahwa LKPD akan menuntun peserta didik dalam membuat mind mapping. LKPD yang sudah dikembangkan dijadikan bahan pelatihan pada guru-guru Sekolah Dasar di kecamatan Banjarsari guna menunjang pembelajaran khususnya dalam mengkaitkan materi dalam tema pada kurikulum 2013.

Kriteria penyusunan LKPD yang harus diperhatikan (Lalla Katriani, 2014:5), yaitu 1) tujuan penyusunan, 2) bahan logis dan sistematis, sesuai dengan kemampuan dan tahap perkembangan peserta didik, menumbuhkan keingintahuan, dan kontekstual. 3) metode, 4) mempertimbangkan kepentingan peserta didik, dan 5) prinsip penggunaan LKPD. Berdasarkan prinsip tersebut pelatihan pembuatan LKPD dikaitkan dengan budaya lokal yang meliputi aspek ekonomi, budaya, teknologi informasi dan komunikasi, serta ekologi (Zuhdan Kun Prasetyo, 2013). Lembar Kerja tersebut sangat bermanfaat pada pembelajaran berbasis budaya dimana lebih mengutamakan aktivitas peserta didik dengan latar budaya yang dimilikinya dengan tujuan menekankan pada pembentukan nilai-nilai karakter budaya bangsa. 


\section{PENUTUP}

Berdasarkan uraian yang dijelaskan tentang kegiatan pengabdian kepada masyarakat dapat disimpulkan sebagai berikut:

1. Pelatihan pembuatan Lembar Kerja Peserta Didik berbasis kearifan lokal Surakarta mempermudah guru untuk mengevaluasi proses belajar peserta didik dalam memahami suatu materi.

2. Adanya peningkatan pengetahuan atau wawasan yang signifikan tentang kontinuitas integrasi dari budaya lokal yang sudah pernah dilaksanakan sebelumnya.

3. Upaya penanaman nilai-nilai karakter budaya bangsa kepada peserta didik melalui LKPD berbasis kearifan lokal.

4. Guru menghasilkan LKPD yang sesuai materi ajar.

Berdasarkan kesimpulan di atas dapat dikemukakan beberapa saran, sebagai berikut:

1. Program pengabdian kepada masyarakat dilakukan secara rutin dan terjadwal sesuai dengan roadmap penelitian.

2. Perlu adanya monitoring dari Kepala Sekolah kepada guru sebagai evaluasi dari implementasi LKPD berbasis kearifan lokal di kelas.

\section{DAFTAR PUSTAKA}

Depdiknas. 2003. Undang-Undang RI tentang Sistem Pendidikan Nasional Nomor 20 Tahun 2003, Bab I, Pasal 1 ayat 19 tentang Kurikulum. Jakarta: Kemendiknas.

Andi Prastowo. 2014. Panduan Kreatif Membuat Bahan Ajar Inovatf: Menciptakan Metode Pembeajaran yag Menarik dan Menyenangkan. Yogyakarta : Diva Press

Toman, dkk. 2013. Extended Worksheet Developed According to Model Based on Construccyivist Learning Approach. International Journal on New Trends in Education and Their Implications, 4 (4): 173-183

Zuhdan Kun Prasetyo. 2013. Pembelajaran Sains Berbasis Kearifan Lokal. Seminar Nasional Fisika dan Pendidkan Fisika. Sukarta, 14 September 2013

Lalla Katriani. 2014. Pengembangan Lembar Kerja Peserta Didik. Makalah PPM. Prodi Pendidikan Fisika UNY. Hal. 1-6 